\author{
O.V. Marchuk ${ }^{1}$, O.V. Smitiukh ${ }^{1}$, Yu. Prots $^{2}$, A.O. Fedorchuk ${ }^{3}$
}

\title{
Crystal Structure of Chalcogenides $\mathrm{R}_{\mathrm{x}} \mathrm{R}{ }_{\mathrm{y}} \mathrm{R}^{\prime \prime}{ }_{\mathrm{z}} \mathrm{PbSi}_{2} \mathrm{~S}_{8}$ $\left(\mathbf{R}^{\prime}-\mathbf{L a}, \mathbf{R}^{\prime \prime}-\mathbf{T b}, \mathbf{R}^{\prime \prime \prime}-\mathbf{E r}\right)$
}

\author{
${ }^{1}$ Lesya Ukrainka Volyn National University, Lutsk, Ukraine, Marchuk.Oleg@vnu.edu.ua \\ ${ }^{2}$ Max-Planck-Institut für Chemische Physik fester Stoffe, Dresden, Germany, prots@cpfs.mpg.de \\ ${ }^{3}$ Stepan Gzhytskyi National University of Veterinary Medicine and Biotechnologies, Lviv, Ukraine, ft@ua.fm
}

\begin{abstract}
The $\mathrm{La}_{\mathrm{x}} \mathrm{Tb}_{\mathrm{y}} \mathrm{Er}_{\mathrm{z}} \mathrm{PbSi}_{2} \mathrm{~S}_{8}$ chalcogenides were obtained by synthesizing the elementary components in vacuum quartz containers at $1320 \mathrm{~K}$. The synthesized alloys were homogenized by annealing at $770 \mathrm{~K}$ during 500 hours. The cell parameters of synthesized sulfides are: $a=0.89576(3) \mathrm{nm}, c=2.65646(8) \mathrm{nm}-\mathrm{La}_{1.2} \mathrm{~Tb}_{0.4} \mathrm{Er}_{0.4} \mathrm{PbSi}_{2} \mathrm{~S}_{8}$; $a=0.89209(1) \mathrm{nm}, \quad c=2.63466(5) \mathrm{nm} \quad-\quad \mathrm{La}_{0.9} \mathrm{~Tb}_{0.2} \mathrm{Er}_{0.9} \mathrm{PbSi}_{2} \mathrm{~S}_{8} ; \quad a=0.89002(3) \mathrm{nm}, \quad c=2.62714(7) \mathrm{nm}-$ $\mathrm{La} 0.67 \mathrm{~Tb}_{0.67} \mathrm{Er}_{0.67} \mathrm{PbSi}_{2} \mathrm{~S}_{8} ; a=0.88993(1) \mathrm{nm}, c=2.62973(4) \mathrm{nm}-\mathrm{La}_{0.6} \mathrm{~Tb}_{1.2} \mathrm{Er}_{0.2} \mathrm{PbSi}_{2} \mathrm{~S}_{8} ; a=0.885161(7) \mathrm{nm}$, $c=2.60445(3) \mathrm{nm}-\mathrm{La}_{0.2} \mathrm{~Tb}_{0.9} \mathrm{Er}_{0.9} \mathrm{PbSi}_{2} \mathrm{~S}_{8}$ respectively.

The statistical mixture of ( $\mathrm{La}, \mathrm{Tb}, \mathrm{Er}, \mathrm{Pb})$ atoms occupy $18 e$ site $\left(\begin{array}{ll}x & y \\ 1 / 4\end{array}\right)$, and $\mathrm{Si}$ atoms occupy $12 c$ site $(1 / 32 / 3 z)$ in the structure of the obtained chalcogenides. Coordinating polyhedra of the statistical mixture $(\mathrm{La}, \mathrm{Tb}$, $\mathrm{Er}, \mathrm{Pb})$ atoms are trigonal prism with two additional atoms $(\mathrm{CN}=8)$, and the $\mathrm{Si}$ atoms occupy the crystallographic point system $12 c$ described with the tetrahedron. According to the experimental results, the synthesized chalcogenides crystallize in the $\mathrm{La}_{2} \mathrm{PbSi}_{2} \mathrm{~S}_{8}$ structure type $(h R 26,167)$. The structure of $\mathrm{La}_{2} \mathrm{PbSi}_{2} \mathrm{~S}_{8}$ is described by using the theory of second anion coordination (SAC).

Keywords: rare earth metals, crystal structure, powder X-ray diffraction, the closest coordination surrounding (CCS), the second coordination surrounding (SCS).
\end{abstract}

Received 11 June 2021; Accepted 15 October 2021.

\section{Introduction}

Search for new crystalline solids with tunable physical properties originating from the synergistic effect of the unique crystal structure and bonding nature is among the main streams in modern material science [1-3]. The properties and crystal structure of multi-component chalcogenides and rare earth metals (REM) containing chalcogenides [4-6], are investigated systematically regarding their practical utilization [7-12]. Adding REM atoms with different chemical nature in terms of $4 f$ electronic level occupancy into the crystal structure of chalcogenides, is a good way to develop semiconductors with desired properties, as such examples are $\mathrm{CaY}_{2} \mathrm{Si}_{2} \mathrm{~S}_{8}: \mathrm{Ce}^{3+} \quad[13], \quad \mathrm{BaLa}_{2} \mathrm{Si}_{2} \mathrm{~S}_{8}: \mathrm{Eu}^{2+} \quad$ [14], $(\mathrm{Gd}, \mathrm{Ce})_{4}(\mathrm{SiS} 4)_{3}, \quad(\mathrm{Y}, \mathrm{Ce})_{4}\left(\mathrm{SiS}_{4}\right)_{3} \quad[15], \quad(\mathrm{La}, \mathrm{Ce}, \mathrm{Y})_{6} \mathrm{Si}_{4} \mathrm{~S}_{17}$ [16], $\mathrm{LaR}^{\prime} \mathrm{PbSi}_{2} \mathrm{~S}_{8}, \mathrm{CeR}^{\prime} \mathrm{PbSi}_{2} \mathrm{~S}_{8}, \mathrm{PrR}^{\prime} \mathrm{PbSi}_{2} \mathrm{~S}_{8}\left(\mathrm{R}^{\prime}=\mathrm{Ce}, \mathrm{Pr}\right.$, Sm, Tb, Dy, Y, Ho and Er) [17] and others. According to the prospects of chalcogenide phases, which crystal structure consists of REM atoms, we can reasonably confirm that the synthesis of multi-component chalcogenides and detailed investigation of the relationship between their crystal structure and properties can be effectively utilized for designing new advanced functional materials.

In this work, we present results of investigations of crystal structures of chalcogenides $\mathrm{La}_{1.2} \mathrm{~Tb}_{0.4} \mathrm{Er}_{0.4} \mathrm{PbSi}_{2} \mathrm{~S}_{8}$, $\mathrm{La}_{0.9} \mathrm{~Tb}_{0.2} \mathrm{Er}_{0.9} \mathrm{PbSi}_{2} \mathrm{~S}_{8}, \quad \mathrm{La}_{0.67} \mathrm{~Tb}_{0.67} \mathrm{Er}_{0.67} \mathrm{PbSi}_{2} \mathrm{~S}_{8}$, $\mathrm{La}_{0.6} \mathrm{~Tb}_{1.2} \mathrm{Er}_{0.2} \mathrm{PbSi}_{2} \mathrm{~S}_{8}$ and $\mathrm{La}_{0.2} \mathrm{~Tb}_{0 .} \mathrm{Er}_{0.9} \mathrm{PbSi}_{2} \mathrm{~S}_{8}$, which are distinct compositions of the quasi-ternary $\mathrm{La}_{2} \mathrm{PbSi}_{2} \mathrm{~S}_{8}-\mathrm{Tb}_{2} \mathrm{PbSi}_{2} \mathrm{~S}_{8}-\mathrm{Er}_{2} \mathrm{PbSi}_{2} \mathrm{~S}_{8}$ system, by using of powder X-ray diffraction method. 


\section{Experimental section}

Samples with stoichiometric compositions for investigation were prepared by co-melting high-purity elements in quartz containers evacuated to a residual pressure of $10^{-2} \mathrm{~Pa}$. The total mass of the original batch for each sample was $1.0 \mathrm{~g}$. The samples were synthesized in an MP-30 programmable electric muffle furnace by heating to $1370 \mathrm{~K}$ at the rate of $12 \mathrm{~K} / \mathrm{h}, 2 \mathrm{~h}$ exposure, cooling to $770 \mathrm{~K}$ at $6 \mathrm{~K} / \mathrm{h}$. Homogenizing annealing at $770 \mathrm{~K}$ for $500 \mathrm{~h}$ was followed by quenching into roomtemperature water without breaking the containers.

The crystal structure of sulfides $\mathrm{La}_{2} \mathrm{PbSi}_{2} \mathrm{~S}_{8}$, $\mathrm{Tb}_{2} \mathrm{PbSi}_{2} \mathrm{~S}_{8}$ and $\mathrm{Er}_{2} \mathrm{PbSi}_{2} \mathrm{~S}_{8}$ was detailly investigated in work [18].

The result of calculations of unit cell of distinct compositions $\mathrm{La}_{2-\mathrm{x}} \mathrm{Er}_{\mathrm{x}} \mathrm{PbSi}_{2} \mathrm{~S}_{8}$ and $\mathrm{La}_{2-\mathrm{x}} \mathrm{Y}_{\mathrm{x}} \mathrm{PbSi}_{2} \mathrm{~S}_{8}$ of solid solution were presented in work [17].

The X-ray powder patterns of samples 1, 2, 4, 5, $9-13,15,16$ and distinct compositions of $\mathrm{Tb}_{2}$ ${ }_{x} \mathrm{Er}_{\mathrm{x}} \mathrm{PbSi}_{2} \mathrm{~S}_{8}$ solid solution were obtained by using a DRON 4-13 powder diffractometer (CuKa radiation, $10^{\circ} \leq 2 \Theta \leq 100^{\circ}$, step scan mode with a step size of $0.05^{\circ}$ and counting time of $20 \mathrm{~s}$ per data point). The unit cell parameters were calculated for these samples (Fig. 1 and Fig. 2).

The powder patterns of samples $3,6,7,8$ i 14 that corresponding to the compositions of $\mathrm{La}_{1.2} \mathrm{~Tb}_{0.4} \mathrm{Er}_{0.4} \mathrm{PbSi}_{2} \mathrm{~S}_{8}, \quad \mathrm{La}_{0.9} \mathrm{~Tb}_{0.2} \mathrm{Er}_{0.9} \mathrm{PbSi}_{2} \mathrm{~S}_{8}$, $\mathrm{La}_{0.67} \mathrm{~Tb}_{0.67} \mathrm{Er}_{0.67} \mathrm{PbSi}_{2} \mathrm{~S}_{8}, \quad \mathrm{La}_{0.6} \mathrm{~Tb}_{1.2} \mathrm{Er}_{0.2} \mathrm{PbSi}_{2} \mathrm{~S}_{8} \quad$ and $\mathrm{La}_{0.2} \mathrm{~Tb}_{0.9} \mathrm{Er}_{0.9} \mathrm{PbSi}_{2} \mathrm{~S}_{8}$ were obtained by using a Powder XHuber Guinier Camera G670 $\left(\mathrm{CuK} \alpha_{1}\right.$ radiation, $\lambda=1.54060 \AA, 3^{\circ}<2 \Theta<100^{\circ}, \Delta 2 \Theta=0.005^{\circ}, 6 \times 30 \mathrm{~min}$ scans). The calculation of $\mathrm{La}_{1.2} \mathrm{~Tb}_{0.4} \mathrm{Er}_{0.4} \mathrm{PbSi}_{2} \mathrm{~S}_{8}$, $\mathrm{La}_{0.9} \mathrm{~Tb}_{0.2} \mathrm{Er}_{0.9} \mathrm{PbSi}_{2} \mathrm{~S}_{8}, \quad \mathrm{La}_{0.67} \mathrm{~Tb}_{0.67} \mathrm{Er}_{0.67} \mathrm{PbSi}_{2} \mathrm{~S}_{8}$, $\mathrm{La}_{0.6} \mathrm{~Tb}_{1.2} \mathrm{Er}_{0.2} \mathrm{PbSi}_{2} \mathrm{~S}_{8}$ and $\mathrm{La}_{0.2} \mathrm{~Tb}_{0.9} \mathrm{Er}_{0.9} \mathrm{PbSi}_{2} \mathrm{~S}_{8}$ crystal structure was performed by using Ritveld's method (program package WinCSD [19]). Visualization of the crystal structure was performed with VESTA program [20].

\section{Results}

The crystal structure of sulfides $\mathrm{La}_{1.2} \mathrm{~Tb}_{0.4} \mathrm{Er}_{0.4} \mathrm{PbSi}_{2} \mathrm{~S}_{8}, \quad \mathrm{La}_{0.9} \mathrm{~Tb}_{0.2} \mathrm{Er}_{0.9} \mathrm{PbSi}_{2} \mathrm{~S}_{8}$, $\mathrm{La}_{0.67} \mathrm{~Tb}_{0.67} \mathrm{Er}_{0.67} \mathrm{PbSi}_{2} \mathrm{~S}_{8}, \quad \mathrm{La}_{0.6} \mathrm{~Tb}_{1.2} \mathrm{Er}_{0.2} \mathrm{PbSi}_{2} \mathrm{~S}_{8} \quad$ and

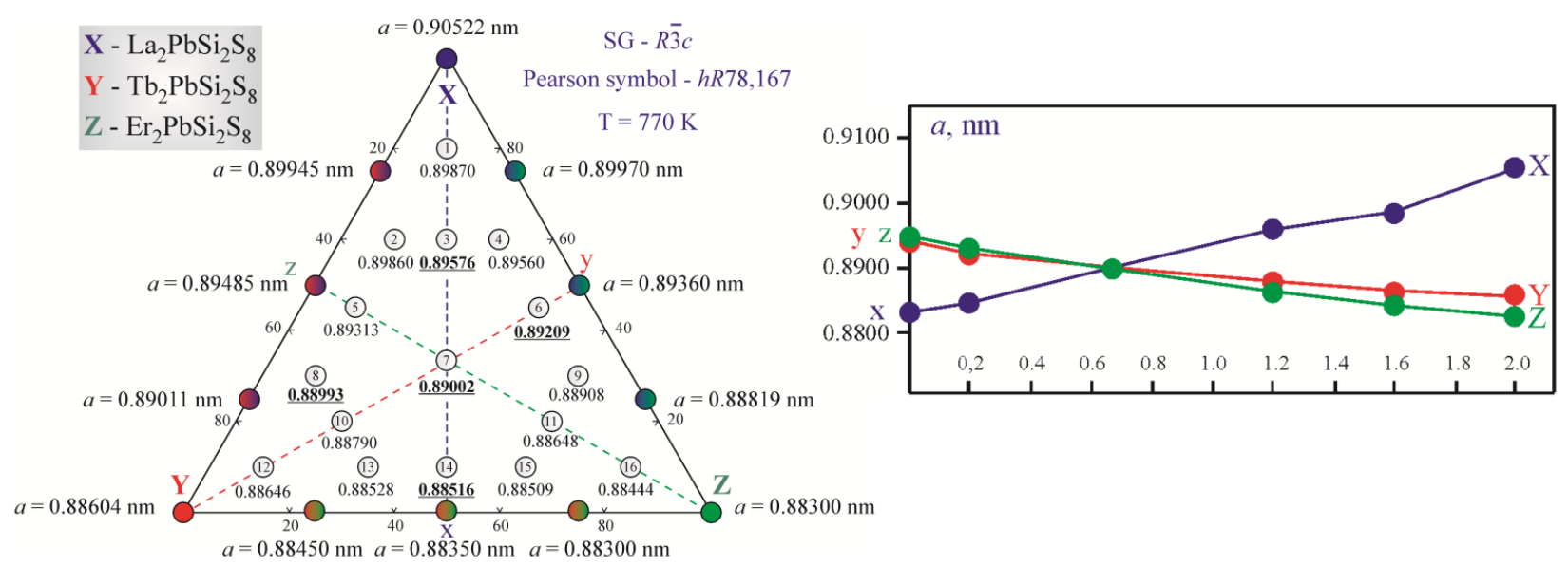

Fig. 1. Unit cell parameter $a$ of sulfides $\mathrm{La}_{2-\mathrm{m}} \mathrm{Tb}_{\mathrm{m}} \mathrm{PbSi}_{2} \mathrm{~S}_{8}(\mathrm{~m}=0 ; 0,5 ; 1,0 ; 1,5 ; 2,0), \mathrm{La}_{2-\mathrm{n}} \mathrm{Er}_{n} \mathrm{PbSi}_{2} \mathrm{~S}_{8}(\mathrm{n}=0 ; 0,5 ; 1,0$; $1,5 ; 2,0), \mathrm{Tb}_{2-\mathrm{k}} \mathrm{Er}_{\mathrm{k}} \mathrm{PbSi}_{2} \mathrm{~S}_{8}(\mathrm{k}=0 ; 0,5 ; 1,0 ; 1,5 ; 2,0)$ and $\mathrm{La}_{\mathrm{x}} \mathrm{Tb}_{\mathrm{y}} \mathrm{Er}_{\mathrm{z}} \mathrm{PbSi}_{2} \mathrm{~S}_{8}$.

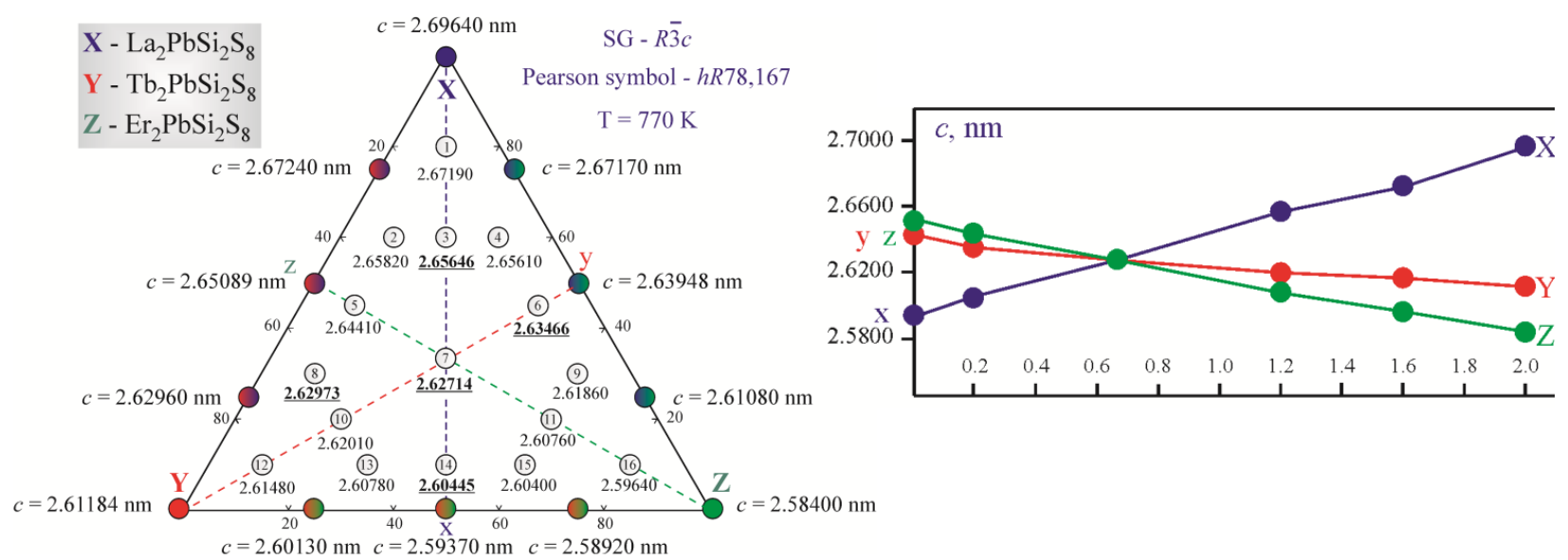

Fig. 2. Unit cell parameter $c$ of sulfides $\mathrm{La}_{2-m} \mathrm{~Tb}_{m} \mathrm{PbSi}_{2} \mathrm{~S}_{8}(\mathrm{~m}=0 ; 0,5 ; 1,0 ; 1,5 ; 2,0), \mathrm{La}_{2-\mathrm{n}} \mathrm{Er}_{n} \mathrm{PbSi}_{2} \mathrm{~S}_{8}(\mathrm{n}=0 ; 0,5 ; 1,0$; $1,5 ; 2,0), \mathrm{Tb}_{2-\mathrm{k}} \mathrm{Er}_{\mathrm{k}} \mathrm{PbSi}_{2} \mathrm{~S}_{8}(\mathrm{k}=0 ; 0,5 ; 1,0 ; 1,5 ; 2,0)$ i $\mathrm{La}_{\mathrm{x}} \mathrm{Tb}_{\mathrm{y}} \mathrm{Er}_{\mathrm{z}} \mathrm{PbSi}_{2} \mathrm{~S}_{8}$. 
$\mathrm{La}_{0.2} \mathrm{~Tb}_{0.9} \mathrm{Er}_{0.9} \mathrm{PbSi}_{2} \mathrm{~S}_{8}$ was investigated by using powder $\mathrm{X}$-ray diffraction method. The powder patterns of these chalcogenides (Fig. 3) were indexed in trigonal space group $R 3-c$.

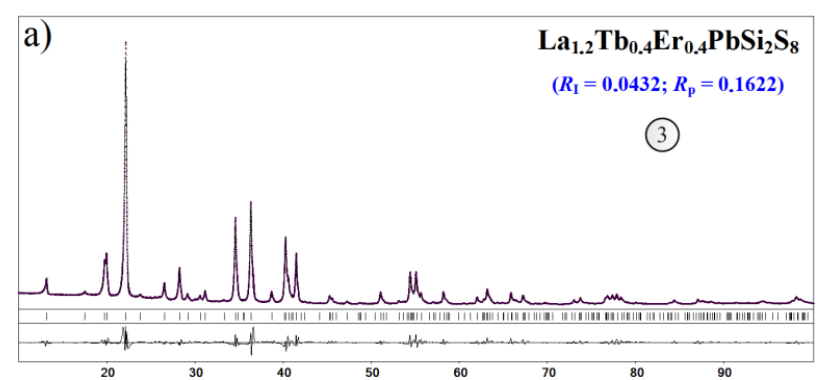

c)

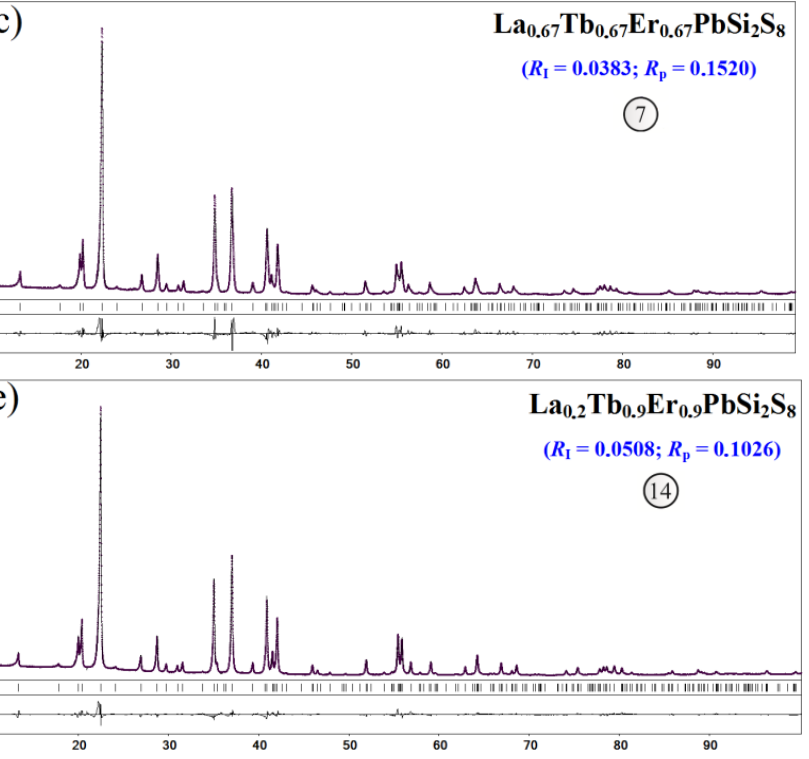

Scan conditions and the results of the crystal structure refinement of obtained sulfides are presented in Tables 1 and 2. Analysis of $h k l$ indexes and their intensities indicates that the crystal structure of obtained
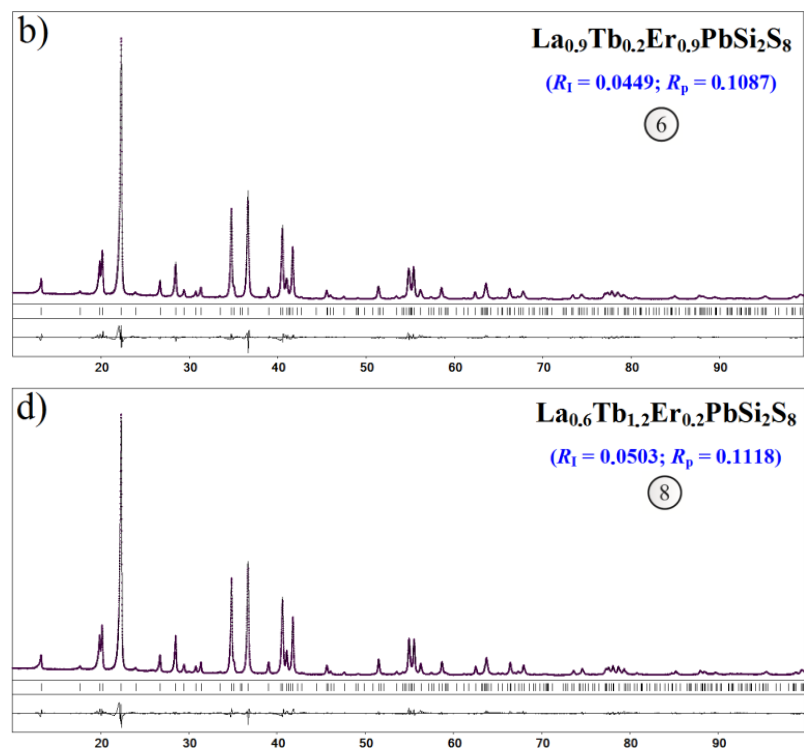

Fig.3. Observed and calculated powder patterns as well as their difference of investigated sulfides

a) $\mathrm{La}_{1.2} \mathrm{~Tb}_{0.4} \mathrm{Er}_{0.4} \mathrm{PbSi}_{2} \mathrm{~S}_{8} ;$ b) $\mathrm{La}_{0.9} \mathrm{~Tb}_{0.2} \mathrm{Er}_{0.9} \mathrm{PbSi}_{2} \mathrm{~S}_{8}$;

c) $\mathrm{La}_{0.67} \mathrm{~Tb}_{0.67} \mathrm{Er}_{0.67} \mathrm{PbSi}_{2} \mathrm{~S}_{8}$;

d) $\mathrm{La}_{0.6} \mathrm{~Tb}_{1.2} \mathrm{Er}_{0.2} \mathrm{PbSi}_{2} \mathrm{~S}_{8} ;$ e) $\mathrm{La}_{0.2} \mathrm{~Tb}_{0.9} \mathrm{Er}_{0.9} \mathrm{PbSi}_{2} \mathrm{~S}_{8}$.

Scan conditions and the results of refinement of the crystal structure of obtained sulfides

Table 1

$\mathrm{La}_{1.2} \mathrm{~Tb}_{0.4} \mathrm{Er}_{0.4} \mathrm{PbSi}_{2} \mathrm{~S}_{8}(\mathrm{~A}), \mathrm{La}_{0.9} \mathrm{~Tb}_{0.2} \mathrm{Er}_{0.9} \mathrm{PbSi}_{2} \mathrm{~S}_{8}(\mathrm{~B})$ and $\mathrm{La}_{0.67} \mathrm{~Tb}_{0.67} \mathrm{Er}_{0.67} \mathrm{PbSi}_{2} \mathrm{~S}_{8}(\mathrm{C})$

\begin{tabular}{|l|c|c|c|}
\hline \multicolumn{1}{|c|}{ Sulfide } & $\mathrm{A}$ & $\mathrm{B}$ & $\mathrm{C}$ \\
\hline$a,(\mathrm{~nm})$ & $0.89576(3)$ & $0.89209(1)$ & $0.89002(3)$ \\
\hline$c,(\mathrm{~nm})$ & $2.65646(8)$ & $2.63466(5)$ & $2.62714(7)$ \\
\hline$V,\left(\mathrm{~nm}^{3}\right)$ & $1.8459(2)$ & $1.8158(8)$ & $1.8022(1)$ \\
\hline Number of atoms in cell $_{\text {Calculated density }\left(\mathrm{g} / \mathrm{cm}^{3}\right)}$ & 78 & 78 & 78 \\
\hline Absorption coefficient $(1 / \mathrm{cm})$ & $4.4585(4)$ & $4.5325(2)$ & $4.5666(3)$ \\
\hline $2 \theta ; \sin \theta / \lambda(\max )$ & 777.79 & 790.69 & 796.64 \\
\hline $\mathrm{R}_{\mathrm{I}}, \mathrm{R}_{\mathrm{P}}$ & $100.20 ; 0.498$ & $99.56 ; 0.496$ & $99.17 ; 0.494$ \\
\hline Scale factor & $0.0432 ; 0.1622$ & $0.0449 ; 0.1087$ & $0.0383 ; 0.1520$ \\
\hline
\end{tabular}

Scan conditions and the results of refinement of the crystal structure of obtained sulfides

Table 2

$\mathrm{La}_{0.6} \mathrm{~Tb}_{1.2} \mathrm{Er}_{0.2} \mathrm{PbSi}_{2} \mathrm{~S}_{8}(\mathrm{D})$ i $\mathrm{La}_{0.2} \mathrm{~Tb}_{0.9} \mathrm{Er}_{0.9} \mathrm{PbSi}_{2} \mathrm{~S}_{8}(\mathrm{E})$

\begin{tabular}{|l|c|c|}
\hline \multicolumn{1}{|c|}{ Sulfide } & $\mathrm{D}$ & $\mathrm{E}$ \\
\hline$a,(\mathrm{~nm})$ & $0.88993(1)$ & $0.885161(7)$ \\
\hline$c,(\mathrm{~nm})$ & $2.62973(4)$ & $2.60445(3)$ \\
\hline$V,\left(\mathrm{~nm}^{3}\right)$ & $1.80364(8)$ & $1.76722(5)$ \\
\hline Number of atoms in cell $^{3}$ & 78 & 78 \\
\hline Calculated density $\left(\mathrm{g} / \mathrm{cm}^{3}\right)$ & $4.5170(2)$ & $4.7699(2)$ \\
\hline Absorption coefficient $(1 / \mathrm{cm})$ & 939.09 & 817.76 \\
\hline $2 \theta ; \sin \theta / \lambda(\max )$ & $99.87 ; 0.497$ & $100.20 ; 0.498$ \\
\hline $\mathrm{R}_{\mathrm{I}}, \mathrm{R}_{\mathrm{P}}$ & $0.0503 ; 0.1118$ & $0.0508 ; 0.1026$ \\
\hline Scale factor & $0.09706(0)$ & $0.09789(0)$ \\
\hline
\end{tabular}


chalcogenides belongs to the structure type $\mathrm{La}_{2} \mathrm{PbSi}_{2} \mathrm{~S}_{8}$ (hR26,167).

Refinement of atomic coordinates and isotropic thermal parameters (Table 3) in the model satisfies the value of the discrepancy factor.

In the structure of chalcogenides $\mathrm{La}_{\mathrm{x}} \mathrm{Tb}_{\mathrm{y}} \mathrm{Er}_{\mathrm{z}} \mathrm{PbSi}_{2} \mathrm{~S}_{8}$, atoms of statistical mixture M1, M2, M3, M4 i M5 are located at the site $-18 e$. The statistical mixture are of the following composition: M1 - 41\% La $13 \% \mathrm{~Tb}, 13 \% \mathrm{Er}$, $33 \% \mathrm{~Pb}, \mathrm{M} 2-30 \% \mathrm{La}, 7 \% \mathrm{~Tb}, 30 \% \mathrm{Er}, 33 \% \mathrm{~Pb}, \mathrm{M} 3$ $-22 \% \mathrm{La}, 22 \% \mathrm{~Tb}, 22 \% \mathrm{Er}, 33 \% \mathrm{~Pb}, \mathrm{M} 4-20 \% \mathrm{La}$, $40 \% \mathrm{~Tb}, 7 \% \mathrm{Er}, 33 \% \mathrm{~Pb}$ i M5 - $7 \% \mathrm{La}, 30 \% \mathrm{~Tb}$, $30 \% \mathrm{Er}, 33 \% \mathrm{~Pb}$. Atoms of Si occupy the site $12 c$, and atoms of Sulfur occupy two sites $12 c$ and $36 f$ (Fig. $4 a$ ). Atoms of statistical mixture $\mathrm{M}(1-5)$ coordinate around themselves eight atoms of $\mathrm{S}$, forming trigonal prisms with

Table 3

Atomic coordinates and anisotropic thermal parameters of $\mathrm{La}_{\mathrm{x}} \mathrm{Tb}_{\mathrm{y}} \mathrm{Er}_{\mathrm{z}} \mathrm{PbSi}_{2} \mathrm{~S}_{8}$

\begin{tabular}{|c|c|c|c|c|c|}
\hline Atom & Site & $x$ & $y$ & $z$ & $\mathrm{~B}_{\mathrm{i} 30} \times 10^{-2}\left(\mathrm{~nm}^{2}\right)$ \\
\hline \multicolumn{6}{|c|}{$\mathrm{La}_{1.2} \mathrm{~Tb}_{0.4} \mathrm{Er}_{0.4} \mathrm{PbSi}_{2} \mathrm{~S}_{8}$} \\
\hline M1 & $18 e$ & $0.3200(1)$ & $0.3200(1)$ & $1 / 4$ & $2.40(2)$ \\
\hline $\mathrm{Si}$ & $12 c$ & $1 / 3$ & $2 / 3$ & $0.3245(3)$ & $2.40(2)$ \\
\hline S1 & $12 c$ & $1 / 3$ & $2 / 3$ & $0.2454(3)$ & $2.40(2)$ \\
\hline S2 & $36 f$ & $0.0351(5)$ & $0.2380(4)$ & $0.1860(2)$ & $2.40(2)$ \\
\hline \multicolumn{6}{|c|}{$\mathrm{La}_{0.9} \mathrm{~Tb}_{0.2} \mathrm{Er}_{0.9} \mathrm{PbSi}_{2} \mathrm{~S}_{8}$} \\
\hline M2 & $18 e$ & $0.32097(9)$ & $0.32097(9)$ & $1 / 4$ & $2.69(2)$ \\
\hline $\mathrm{Si}$ & $12 c$ & $1 / 3$ & $2 / 3$ & $0.3238(2)$ & $2.69(2)$ \\
\hline S1 & $12 c$ & $1 / 3$ & $2 / 3$ & $0.2447(2)$ & $2.69(2)$ \\
\hline S2 & $36 f$ & $0.0350(4)$ & $0.2389(3)$ & $0.18664(9)$ & $2.69(2)$ \\
\hline \multicolumn{6}{|c|}{$\mathrm{La}_{0.67} \mathrm{~Tb}_{0.67} \mathrm{Er}_{0.67} \mathrm{PbSi}_{2} \mathrm{~S}_{8}$} \\
\hline $\mathrm{M} 3$ & $18 e$ & $0.3214(1)$ & $0.3214(1)$ & $1 / 4$ & $2.53(2)$ \\
\hline $\mathrm{Si}$ & $12 c$ & $1 / 3$ & $2 / 3$ & $0.3238(3)$ & $2.53(2)$ \\
\hline S1 & $12 c$ & $1 / 3$ & $2 / 3$ & $0.2435(2)$ & $2.53(2)$ \\
\hline S2 & $36 f$ & $0.0354(4)$ & $0.2416(3)$ & $0.1873(1)$ & $2.53(2)$ \\
\hline \multicolumn{6}{|c|}{$\mathrm{La}_{0.6} \mathrm{~Tb}_{1.2} \mathrm{Er}_{0.2} \mathrm{PbSi}_{2} \mathrm{~S}_{8}$} \\
\hline M4 & $18 e$ & $0.32098(9)$ & $0.32098(9)$ & $1 / 4$ & $2.83(2)$ \\
\hline $\mathrm{Si}$ & $12 c$ & $1 / 3$ & $2 / 3$ & $0.3248(2)$ & $2.83(2)$ \\
\hline S1 & $12 c$ & $1 / 3$ & $2 / 3$ & $0.2442(2)$ & $2.83(2)$ \\
\hline S2 & $36 f$ & $0.0353(4)$ & $0.2397(3)$ & $0.18587(9)$ & $2.83(2)$ \\
\hline \multicolumn{6}{|c|}{$\mathrm{La}_{0.2} \mathrm{~Tb}_{0.9} \mathrm{Er}_{0.9} \mathrm{PbSi}_{2} \mathrm{~S}_{8}$} \\
\hline M5 & $18 e$ & $0.32169(7)$ & $0.32169(7)$ & $1 / 4$ & $3.00(1)$ \\
\hline $\mathrm{Si}$ & $12 c$ & $1 / 3$ & $2 / 3$ & $0.3252(2)$ & $3.00(1)$ \\
\hline S1 & $12 c$ & $1 / 3$ & $2 / 3$ & $0.2434(2)$ & $3.00(1)$ \\
\hline S2 & $36 f$ & $0.0357(3)$ & $0.2420(3)$ & $0.18706(7)$ & $3.00(1)$ \\
\hline
\end{tabular}

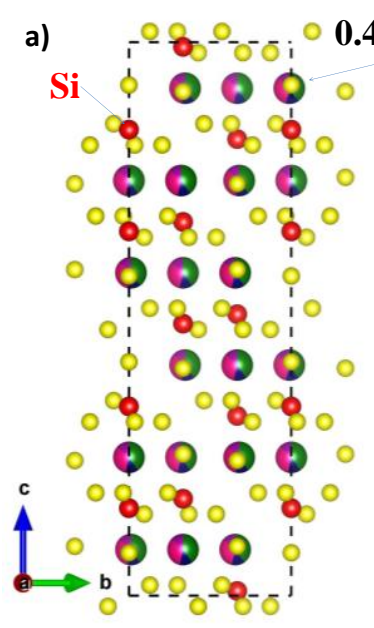

\section{$0.402 \mathrm{La}+0.124 \mathrm{~Tb}+0.124 \mathrm{Er}+0.333 \mathrm{~Pb}$}
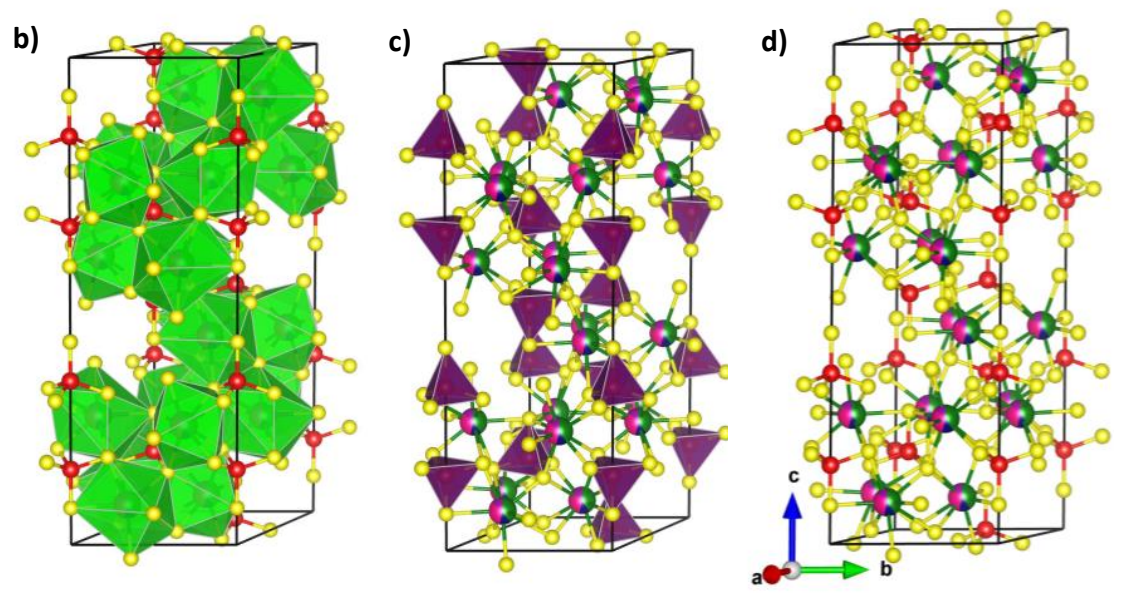

Fig. 4. Unit cell and the coordination polyhedra of the $\mathrm{La}_{x} \mathrm{~Tb}_{\mathrm{y}} \mathrm{Er}_{\mathrm{z}} \mathrm{PbSi}_{2} \mathrm{~S}_{8}$ chalcogenides structure. 
two additional atoms $\left[\mathrm{M}(1-5) 6 \mathrm{~S}_{2} 2 \mathrm{~S}_{1}\right]$ (Fig. 4b), and atoms of Silicon, occupying the site $12 c$, have tetrahedral surrounding [Si $1 \mathrm{~S}_{1} 3 \mathrm{~S}_{2}$ ] (Fig. 4c). 3D-model of the unit cell in the structure of the above-described chalcogenides are presented in Figure $4 d$.

The inter-atomic distances $\delta(\mathrm{M} 1-\mathrm{S}), \delta(\mathrm{M} 2-\mathrm{S})$, $\delta(\mathrm{M} 3-\mathrm{S}), \delta(\mathrm{M} 4-\mathrm{S}), \delta(\mathrm{M} 5-\mathrm{S}), \delta(\mathrm{Si}-\mathrm{S})$ and coordination numbers in the structure of $\mathrm{La}_{\mathrm{x}} \mathrm{Tb}_{\mathrm{y}} \mathrm{Er}_{\mathrm{z}} \mathrm{PbSi}_{2} \mathrm{~S}_{8}$ compound are presented in Tables 4-6.

It is worth noticing of regular change of inter-atomic distances $\delta(\mathrm{M}-\mathrm{S})$ of the structure of chalcogenides $\mathrm{La}_{0.2} \mathrm{~Tb}_{0.9} \mathrm{Er}_{0.9} \mathrm{PbSi}_{2} \mathrm{~S}_{8}, \quad \mathrm{La}_{0.67} \mathrm{~Tb}_{0.67} \mathrm{Er}_{0.67} \mathrm{PbSi}_{2} \mathrm{~S}_{8}$, $\mathrm{La}_{1.2} \mathrm{~Tb}_{0.4} \mathrm{Er}_{0.4} \mathrm{PbSi}_{2} \mathrm{~S}_{8}$ and $\mathrm{La}_{2} \mathrm{PbSi}_{2} \mathrm{~S}_{8}$, in which stoichiometric composition is on the height $x X$ of GibbsRoozeboom's triangular (Fig. 1 and Fig. 2).

With an increase in the content of $\mathrm{La}$ $\left(\mathrm{r}\left(\mathrm{La}^{3+}\right)=0.130 \mathrm{~nm},[21]\right)$ and, accordingly, a decrease in the content of $\mathrm{Tb}\left(\mathrm{r}\left(\mathrm{Tb}^{3+}\right)=0.118 \mathrm{~nm}\right)$ and $\mathrm{Er}$ $\left(\mathrm{r}\left(\mathrm{Er}^{3+}\right)=0.114 \mathrm{~nm}\right)$ in the site $18 e$ there is a regular increase interatomic distances $\delta(\mathrm{M}-\mathrm{S})_{\min }$ from 0.2794 to $0.2880 \mathrm{~nm}$; interatomic distances $\delta(\mathrm{M}-\mathrm{S})_{\max }$ increase from 0.3241 to $0.3278 \mathrm{~nm}$ (Fig. 5).

For the heights $y Y$ and $z Z$, it is regularly to expect a reduction of inter-atomic distances $\delta(\mathrm{M}-\mathrm{S})$ since the contents of REM, which has lower ionic radii, is growing at site $18 e$. These patterns correlate well with the change in the parameters $a$ and $c$ of the unit cell of sulfides, the stoichiometric composition of which falls at the heights $x X, y Y$ and $z Z$ of the Gibbs-Rooseboom triangle (Fig. 1 and Fig. 2).

\section{Discussion of results}

The compounds, in which structure cations of heavy atoms are located within the anionic sublattice of light atoms, can reveal interesting physical properties [22, 23].

Table 4

The inter-atomic distances $\delta(\mathrm{nm})$ and coordination numbers $(\mathrm{CN})$ of the atoms of the structure $\operatorname{La}_{\mathrm{x}} \mathrm{Tb}_{\mathrm{y}} \mathrm{Er}_{\mathrm{z}} \mathrm{PbSi}_{2} \mathrm{~S}_{8}$

\begin{tabular}{|c|c|c|c|c|c|c|c|}
\hline \multicolumn{2}{|c|}{ Atoms } & $\delta, \mathrm{nm}$ & $\mathrm{CN}$ & & s & $\delta, \mathrm{nm}$ & $\mathrm{CN}$ \\
\hline \multicolumn{4}{|c|}{$\mathrm{La}_{1.2} \mathrm{~Tb}_{0.4} \mathrm{Er}_{0.4} \mathrm{PbSi}_{2} \mathrm{~S}_{8}$} & \multicolumn{4}{|c|}{$\mathrm{La}_{0.9} \mathrm{~Tb}_{0.2} \mathrm{Er}_{0.9} \mathrm{PbSi}_{2} \mathrm{~S}_{8}$} \\
\hline \multirow{4}{*}{ M1 } & $-2 \mathrm{~S} 2$ & $0,2840(4)$ & \multirow{4}{*}{8} & \multirow{4}{*}{ M2 } & $-2 \mathrm{~S} 2$ & $0,2822(3)$ & \multirow{4}{*}{8} \\
\hline & $-2 \mathrm{~S} 2$ & $0,2955(4)$ & & & $-2 \mathrm{~S} 2$ & $0,2941(3)$ & \\
\hline & $-2 \mathrm{~S} 1$ & $0,3050(1)$ & & & $-2 \mathrm{~S} 1$ & $0,30335(8)$ & \\
\hline & $-2 \mathrm{~S} 2$ & $0,3282(4)$ & & & $-2 \mathrm{~S} 2$ & $0,3263(3)$ & \\
\hline \multirow{2}{*}{$\mathrm{Si}$} & $-1 \mathrm{~S} 1$ & $0,2099(11)$ & \multirow{2}{*}{4} & \multirow{2}{*}{$\mathrm{Si}$} & $-1 \mathrm{~S} 1$ & $0,2085(7)$ & \multirow{2}{*}{4} \\
\hline & $-3 \mathrm{~S} 2$ & $0,2129(5)$ & & & $-3 \mathrm{~S} 2$ & $0,2139(3)$ & \\
\hline
\end{tabular}

Table 5

The inter-atomic distances $\delta(\mathrm{nm})$ and coordination numbers $(\mathrm{CN})$ of the atoms of the structure $\mathrm{La}_{\mathrm{x}} \mathrm{Tb}_{\mathrm{y}} \mathrm{Er}_{\mathrm{z}} \mathrm{PbSi}_{2} \mathrm{~S}_{8}$

\begin{tabular}{|c|c|c|c|c|c|c|c|}
\hline \multicolumn{2}{|c|}{ Atoms } & $\delta, \mathrm{nm}$ & $\mathrm{CN}$ & & as & $\delta, \mathrm{nm}$ & $\mathrm{CN}$ \\
\hline \multicolumn{4}{|c|}{$\mathrm{La}_{0.67} \mathrm{~Tb}_{0.67} \mathrm{Er}_{0.67} \mathrm{PbSi}_{2} \mathrm{~S}_{8}$} & \multicolumn{4}{|c|}{$\mathrm{La}_{0.6} \mathrm{~Tb}_{1.2} \mathrm{Er}_{0.2} \mathrm{PbSi}_{2} \mathrm{~S}_{8}$} \\
\hline \multirow{4}{*}{ M3 } & $-2 \mathrm{~S} 2$ & $0.2808(3)$ & \multirow{4}{*}{8} & \multirow{4}{*}{ M4 } & $-2 \mathrm{~S} 2$ & $0.2827(3)$ & \multirow{4}{*}{8} \\
\hline & $-2 \mathrm{~S} 2$ & $0.2942(3)$ & & & $-2 \mathrm{~S} 2$ & $0.2915(3)$ & \\
\hline & $-2 \mathrm{~S} 1$ & $0.3026(1)$ & & & $-2 \mathrm{~S} 1$ & $0.30268(9)$ & \\
\hline & $-2 \mathrm{~S} 2$ & $0.3254(3)$ & & & $-2 \mathrm{~S} 2$ & $0.3269(3)$ & \\
\hline \multirow{2}{*}{$\mathrm{Si}$} & $-1 \mathrm{~S} 1$ & $0.2109(8)$ & \multirow{2}{*}{4} & \multirow{2}{*}{$\mathrm{Si}$} & $-1 \mathrm{~S} 1$ & $0.2120(8)$ & \multirow{2}{*}{4} \\
\hline & $-3 \mathrm{~S} 2$ & $0.2163(4)$ & & & $-3 \mathrm{~S} 2$ & $0.2124(3)$ & \\
\hline
\end{tabular}

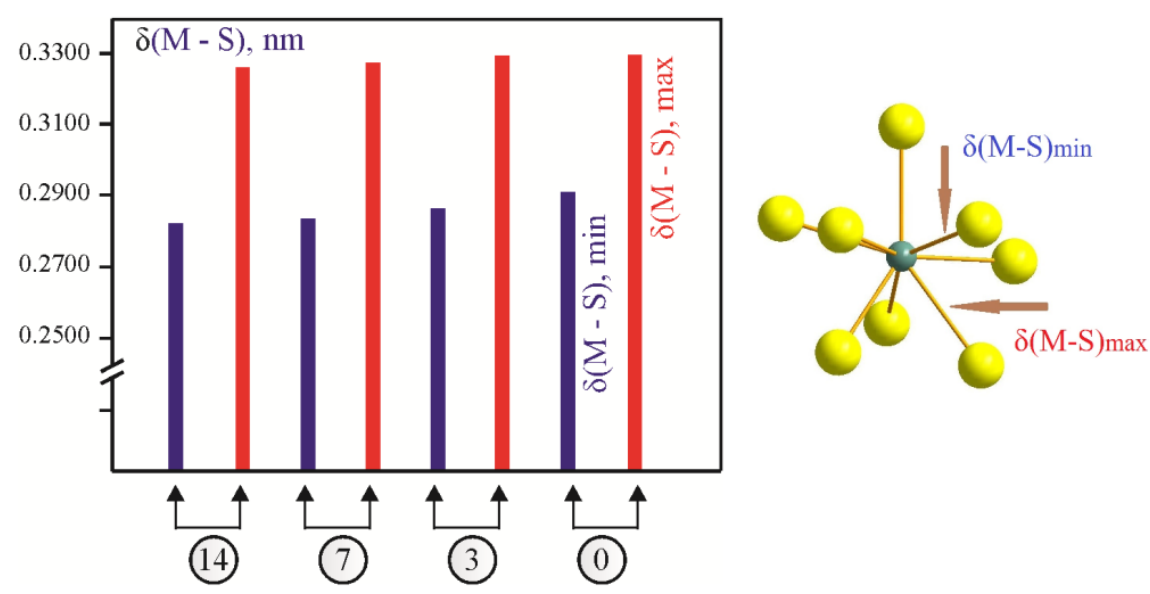

Fig. 5. The inter-atomic distances $\delta(\mathrm{M}-\mathrm{S})$ of the structure of sulfides $\mathrm{La}_{\mathrm{x}} \mathrm{Tb}_{\mathrm{y}} \mathrm{Er}_{\mathrm{z}} \mathrm{PbSi}_{2} \mathrm{~S}_{8}$ : $14-\mathrm{La}_{0.2} \mathrm{~Tb}_{0.9} \mathrm{Er}_{0.9} \mathrm{PbSi}_{2} \mathrm{~S}_{8} ; 7-\mathrm{La}_{0.67} \mathrm{~Tb}_{0.67} \mathrm{Er}_{0.67} \mathrm{PbSi}_{2} \mathrm{~S}_{8} ; 3-\mathrm{La}_{1.2} \mathrm{~Tb}_{0.4} \mathrm{Er}_{0.4} \mathrm{PbSi}_{2} \mathrm{~S}_{8}$ and $0-\mathrm{La}_{2} \mathrm{PbSi}_{2} \mathrm{~S}_{8}$. 
Table 6

The inter-atomic distances $\delta(\mathrm{nm})$ and coordination numbers $(\mathrm{CN})$ of the atoms of the structure

$\mathrm{La}_{0.2} \mathrm{~Tb}_{0.9} \mathrm{Er}_{0.9} \mathrm{PbSi}_{2} \mathrm{~S}_{8}$

\begin{tabular}{|c|c|c|c|}
\hline \multicolumn{2}{|c|}{ Atoms } & $\delta, \mathrm{nm}$ & \multirow{2}{*}{$\mathrm{CN}$} \\
\hline \multirow{4}{*}{ M5 } & $-2 \mathrm{~S} 2$ & $0.2794(2)$ & \multirow{2}{*}{} \\
\cline { 2 - 3 } & $-2 \mathrm{~S} 2$ & $0.2910(2)$ & \multirow{2}{*}{8} \\
\cline { 2 - 3 } & $-2 \mathrm{~S} 1$ & $0.30084(7)$ & \\
\cline { 2 - 3 } & $-2 \mathrm{~S} 2$ & $0.3241(2)$ & \\
\hline \multirow{2}{*}{$\mathrm{Si}$} & $-1 \mathrm{~S} 1$ & $0.2130(6)$ & \multirow{2}{*}{4} \\
\cline { 2 - 3 } & $-3 \mathrm{~S} 2$ & $0.2137(3)$ & \\
\hline
\end{tabular}

The probability of formation of new compounds increases in the systems where initial components are different significantly with their chemical and physical properties, as an example of such is a quasi-ternary $\mathrm{La}_{2} \mathrm{~S}_{3}$ - $\mathrm{PbS}-\mathrm{SiS}_{2}$ system (Fig. 6), in which exists the quaternary $\mathrm{La}_{2} \mathrm{PbSi}_{2} \mathrm{~S}_{8}$ compound, which crystallizes in its own structure type ( $h R 26.167$ [8]). The crystal structure of obtained chalcogenides belongs to the structure type $\mathrm{La}_{2} \mathrm{PbSi}_{2} \mathrm{~S}_{8}$. The ternary sulfide $\mathrm{La}_{2} \mathrm{PbS}_{4}, \mathrm{La}_{2} \mathrm{SiS}_{5}$ i $\mathrm{Pb}_{2} \mathrm{SiS}_{4}$ compounds exist in the quasi-binary $\mathrm{La}_{2} \mathrm{~S}_{3}-\mathrm{PbS}$, $\mathrm{La}_{2} \mathrm{~S}_{3}-\mathrm{SiS}_{2}$ and $\mathrm{PbS}-\mathrm{SiS}_{2}$ systems, respectively.

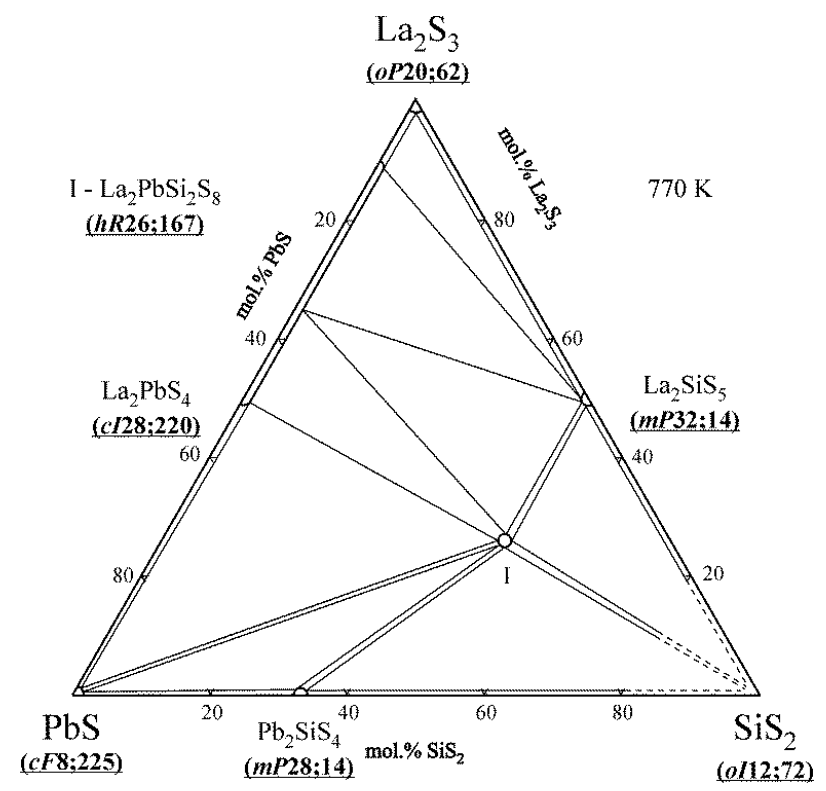

Fig. 6. The quasi-ternary $\mathrm{La}_{2} \mathrm{~S}_{3}-\mathrm{PbS}-\mathrm{SiS}_{2}$ system at the $770 \mathrm{~K}$.

In the structure of the $\mathrm{PbS}$ and $\mathrm{SiS}_{2}$ compounds, the second coordination surrounding (SCS) of anionic atoms has a form of the cuboctahedron, and such a situation indicates the predominant component of the ionic type of interaction, and asymmetric SCS of the $\mathrm{La}_{2} \mathrm{~S}_{3}$ structure indicates the significantly covalent component.

In the $\mathrm{PbS}$ structure ( $c F 8.225$ [24]), atoms of Lead are located in the octahedral cavities of the SCS; and in the structure of $\mathrm{SiS}_{2}$ (oI12.72) [25]), atoms of Silicon are located in the tetrahedral cavities of the SCS (Fig. 7). In other words, a bigger atom occupies bigger cavities; fewer atoms occupy less ones where in the nodes of the anionic sublattice are sulfur atoms. The dense
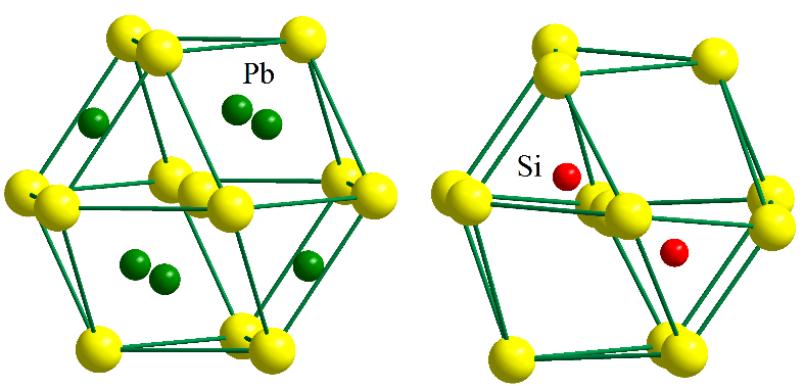

Fig. 7. SCS of atoms of Sulfur of the structure $\mathrm{PbS}$ $(c F 8.225)$ and $\mathrm{SiS}_{2}(o I 12.72)$.

arrangement of atoms and the large difference in the electronegativities of the sulfur atoms and the $p$-elements of the sixth group indicate the ionic type of bond in the $\mathrm{PbS}$ and $\mathrm{SiS}_{2}$ compounds.

In the structure of $\mathrm{La}_{2} \mathrm{~S}_{3}$ (oP20.62 [26.27]), atoms of Lanthanum are located in the trigonal prisms with two additional atoms of Sulfur against the side faces. Such a surrounding testifies that despite the big difference of electronegativity of atoms $\mathrm{La}$ and $\mathrm{S}$, the dense arrangement of atoms is not observed.

In the process of interactions between sulfides of $\mathrm{Pb}$ and $\mathrm{Si}$ comes to existence $\mathrm{Pb}_{2} \mathrm{SiS}_{4}$ compound ( $m P 28.14$ [28]), in which structure the anionic type of sublattice are saved, that is why as in the original sulfides it looks like the cuboctahedron (Fig. 8).

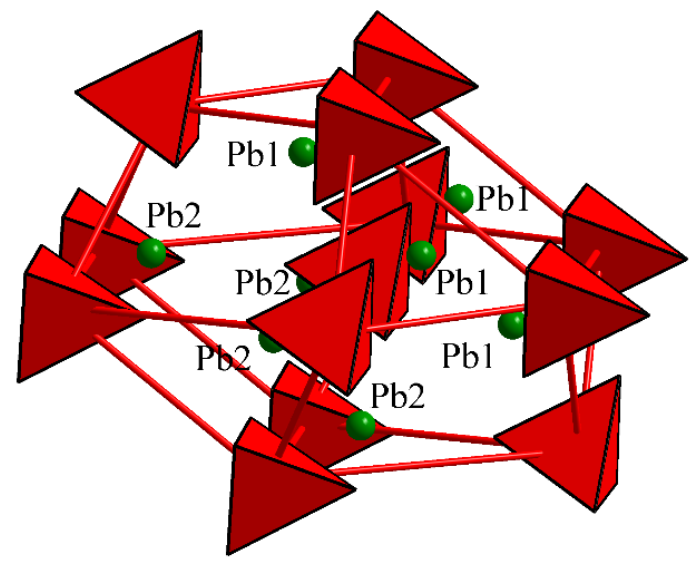

Fig. 8. SCS of atoms anionic group $\left[\mathrm{SiS}_{4}\right]^{4-}$ of the structure of $\mathrm{Pb}_{2} \mathrm{SiS}_{4}$ compound ( $\left.m P 28.14\right)$.

Due to the interaction of sulfides of two competing $\mathrm{p}$ elements, more electronegative Silicon forms the tetrahedral surrounding, and these tetrahedra are considered like anions, and less electronegative Lead occupies the cation site. In this case, it can be argued that there are tetrahedra $\left[\mathrm{SiS}_{4}\right]$ in the anionic sublattice nodes, and as a result, the atoms of Lead will occupy smaller cavities within the SCS - tetrahedra of anion atoms. The closest coordination surrounding (CCS) of the atoms of Lead are trigonal prisms of sulfur atoms. Due to the fact that the anions have become larger, and the atoms of $\mathrm{Pb}$ occupy a favorable position for them, we have the preservation of the anionic sublattice and Silicon becomes an anion-forming element.

From the point of view of the structure and the properties of sulfides, which have pronounced ionic 
properties, it is interesting to introduce into their structure rare earth elements, which in the structure of binary sulfides form covalent bonds $\mathrm{R}-\mathrm{S}$. In the structure of binary sulfides, REM atoms form the closest surrounding, which is not characteristic of dense stacking (these are usually trigonal prisms with additional atoms). REM atoms do not form ionic structures, but when they are incorporated into an ionic structure, it is possible to form crystal structures where dense packages are formed. An example of such a structure is $\mathrm{La}_{2} \mathrm{SiS}_{5}(m P 32.14$ [29]) where $\mathrm{Si}_{2} \mathrm{~S}_{8}{ }_{8}^{8-}$ ions are located in the anionic sublattice nodes. Atoms of the cationic group in the form of tetrahedra of lanthanum atoms around sulfur atoms are located in tetrahedral cavities within the SCS. The polyhedra of the cationic group are connected by edges and vertices. The CCS of Lanthanum atoms has the form of trigonal prisms with two (for La1) and three (for La2) additional atoms against the side faces.
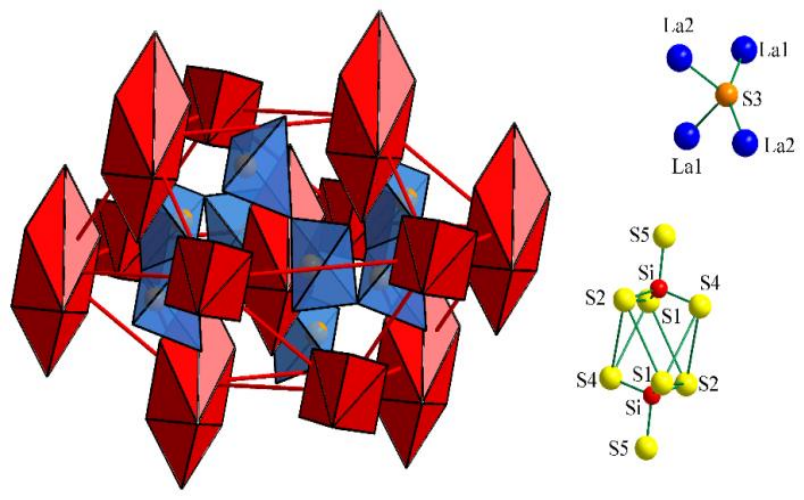

Fig. 9. $\mathrm{SCS}$ of atoms of the anionic group $\left[\mathrm{Si}_{2} \mathrm{~S}_{8}{ }^{8-}\right]$ of the structure of $\mathrm{La}_{2} \mathrm{SiS}_{5}(m P 32.14)$.

In the crystal structure of $\mathrm{La}_{2} \mathrm{PbS}_{4}(c I 28.220$ [30]), the formation of trigonal prisms with two additional sulfur atoms is characteristic for Lanthanum atoms. In the structure of the $\mathrm{La}_{2} \mathrm{PbS}_{4}$ compound, SCS of Sulfur atoms in the form of asymmetric polyhedra with eleven atoms indicates a significant covalent component in the bonds, and therefore to emit ions and cations incorrectly.

Hence, the quasi-ternary $\mathrm{La}_{2} \mathrm{~S}_{3}-\mathrm{PbS}-\mathrm{SiS}_{2}$ system is unique since the crystal structure of the part of the original phases can be described by SCS in the form of the cuboctahedron. However, adding REM creates a platform for the emergence of non-standard structural fragments. This leads to the fact that the crystal structure of $\mathrm{La}_{2} \mathrm{PbSiS}_{8}$ ( $h R 26,167)$ can also be considered as dense ion stacking. The SCS of the compound is in the form of the cuboctahedron (Fig. 10) where $\mathrm{Si}_{2} \mathrm{~S}_{8}{ }^{8-}$ ions are located in the anionic sublattice nodes of $\mathrm{La}_{2} \mathrm{SiS}_{5}$. The cationic atoms are located at the boundary of tetrahedral and octahedral cavities within SCS and have CCS in the form of trigonal prisms of sulfur atoms.

The analysis of the $\mathrm{La}_{2} \mathrm{PbSiS}_{8}$ crystal structure indicates its prospect as a nonlinear optical material. The peculiarity of the structure of $\mathrm{La}_{2} \mathrm{PbSiS}_{8}$ is that the positions of Lanthanum can be purposefully replaced by different atoms of REM, which greatly expands the possibilities for the synthesis of new compounds with promising properties.
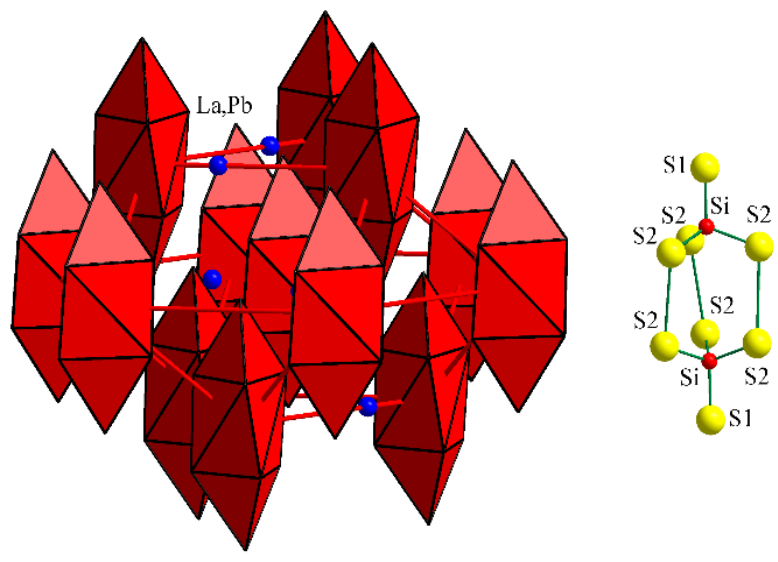

Рис. 10. ДКО атомів аніонної групи у структурі сполуки $\mathrm{La}_{2} \mathrm{PbSiS}_{8}(h R 28,167)$.

\section{Conclusions}

In this work, we present the results of the crystal structure investigation of complex chalcogenide phases $\mathrm{La}_{1.2} \mathrm{~Tb}_{0.4} \mathrm{Er}_{0.4} \mathrm{PbSi}_{2} \mathrm{~S}_{8}, \quad \mathrm{La}_{0.9} \mathrm{~Tb}_{0.2} \mathrm{Er}_{0.9} \mathrm{PbSi}_{2} \mathrm{~S}_{8}$, $\mathrm{La}_{0.67} \mathrm{~Tb}_{0.67} \mathrm{Er}_{0.67} \mathrm{PbSi}_{2} \mathrm{~S}_{8}, \quad \mathrm{La}_{0.6} \mathrm{~Tb}_{1.2} \mathrm{Er}_{0.2} \mathrm{PbSi}_{2} \mathrm{~S}_{8} \quad$ and $\mathrm{La}_{0.2} \mathrm{~Tb}_{0.9} \mathrm{Er}_{0.9} \mathrm{PbSi}_{2} \mathrm{~S}_{8}$ which are the distinct compositions of continuous solid solutions of the quasi-ternary $\mathrm{La}_{2} \mathrm{PbSi}_{2} \mathrm{~S}_{8}-\mathrm{Tb}_{2} \mathrm{PbSi}_{2} \mathrm{~S}_{8}-\mathrm{Er}_{2} \mathrm{PbSi}_{2} \mathrm{~S}_{8}$ system. These phases are obtained by populating the site $18 e$ ( $x$ y $1 / 4)$ with atoms of different REM. Their crystal structure belongs to the structural type $\mathrm{La}_{2} \mathrm{PbSiS}_{8}(h R 26.167)$.

The crystal structure of the $\mathrm{La}_{2} \mathrm{PbSiS}_{8}$ compound from the standpoint of the theory of SCS is described for the first time. The crystal structure of the $\mathrm{La}_{2} \mathrm{PbSiS}_{8}$ is unique because the part of this structure can be described through the second coordination surrounding. However, another part, which includes La atoms cannot be described through the second coordination surrounding because of the big coordination number of atoms La. Thereby, the compound has more ionic bonds than covalent ones. Such types of bonds indicate the high possibility of good optical properties of the studied compounds.

Marchuk O.V. - PhD., Associate Professor, Associate Professor of Chemistry and Technology;

Smitiukh O.V. - PhD., senior laboratory assistant of the Department of Chemistry and Technology;

Prots Yu. - Ph.D., Co-worker of the Department of Chemical Metals Science;

Fedorchuk A.O. - Doctor of Technical Sciences, Professor, Professor of the Department of Biological and General Chemistry.
[1] G. Tan, L. D. Zhao, M. G. Kanatzidis, https://doi.org/10.1021/acs.chemrev.6b00255).


[2] X. L. Shi, J. Zou, Z. G. Chen, Chem. Rev. 120, 7399 (2020); https://doi.org/10.1021/acs.chemrev.0c00026.

[3] C. Celania, A.-V. Mudring, J. Solid State Chem. 274, 243 (2019); https://doi.org/10.1016/j.jssc.2019.03.009.

[4] T. Parashchuk, I. Horichok, A. Kosonowski, O. Cherniushok, P. Wyzga, G. Cempura, A. Kruk, K. Wojciechowski, J. Alloys Compd. 860, 158355 (2021); https://doi.org/10.1016/i.jallcom.2020.158355).

[5] A.O. Fedorchuk, O.V. Parasyuk, O. Cherniushok, B. Andriyevsky, G.L. Myronchuk, O.Y. Khyzhun, G. Lakshminarayana, J. Jedryka, I.V. Kityk, A.M. ElNaggar, A.A. Albassam, M. Piasecki, J. Alloys Compd. 740, 294 (2018); https://doi.org/10.1016/j.jallcom.2017.12.353.

[6] O. Cherniushok, R. Cardoso-Gil, T. Parashchuk, Y. Grin, K. T. Wojciechowski, Inorg. Chem. 60, 2771 (2021); https://doi.org/10.1021/acs.inorgchem.0c03549.

[7] M. Daszkiewicz, L.D. Gulay, V.Ya. Shemet, Acta $\quad$ Cryst $\quad$ B. 64(2), 172 (2008); https://doi.org/10.1107/S0108768108004175.

[8] L.D. Gulay, M. Daszkiewicz, I.P. Ruda, O.V. Marchuk, Acta Cryst. C. $\quad$ 66(3), i19 (2010); https://doi.org/10.1107/S0108270110000247.

[9] H-Y. Zeng, F-K. Zheng, G-C. Guo, J-S. Huang, J. Alloys Compd. 458, 123 (2008); https://doi.org/10.1016/j.jallcom.2007.03.136.

[10] Y. Nanai, C. Sasaki, Yu Sakamoto, T. Okuno, J. Phys. D: Appl. Phys. 44, 405402 (2011); https://doi.org/10.1088/0022-3727/44/40/405402.

[11] A. Choudhury, P.K. Dorhout, Z. Anorg. Allg. Chem. 634, $649 \quad$ (2008); https://doi.org/10.1002/zaac.200700511.

[12] Y. Nanai, Y. Suzuki, T. Okuno, J. Phys. D: Appl. Phys. 49, 105103 (2016); https://doi.org/10.1088/00223727/49/10/105103.

[13] S.P. Lee, C.H. Huang, T.M. Chen, J. Mater. Chem. C. 2(42), 8925 (2014); https://doi.org/10.1039/c4tc01572j.

[14] S.P. Lee, T.S. Chan, T.M. Chen, ACS Appl. Mater. Interfaces. 7(1), $40 \quad$ (2015); https://doi.org/10.1021/am505613s.

[15] Y. Nanai, K. Suzuki, T. Okuno, Mater. Res. Express. 2, 036203 (2015); https://doi.org/10.1088/2053$1591 / 2 / 3 / 036203$.

[16] Y. Nanai, H. Kamioka, T. Okuno, J. Phys. D Appl. Phys. 51, 135103 (2018); https://doi.org/10.1088/13616463/aaaf5e.

[17] D. Kaczorowski, Kh.O. Melnychuk, O.V Marchuk, L.D. Gulay, M. Daszkiewicz, J. Solid State Chem. 290, 121565 (2020); https://doi.org/10.1016/j.jssc.2020.121565.

[18] M. Daszkiewicz, O.V. Marchuk, L.D. Gulay, D. Kaczorowski, J. Alloys compd. 519, 85 (2012); https://doi.org/10.1016/j.jallcom.2011.12.097.

[19] L. Akselrud, Yu. Grin. J. Appl. Cryst. 47, 803 (2014); https://doi.org/10.1107/S1600576714001058.

[20] K. Momma, F. Izumi, J. Appl. Crystallogr. 44, 1272 (2011); https://doi.org/10.1107/S0021889811038970.

[21] R.D. Shannon, Acta Cryst. A. 39, 751 (1976); https://doi.org/10.1107/S0567739476001551.

[22] R. Ahiska, D. Freik, T. Parashchuk, I. Gorichok, Turk. J. Phys. 38(1), 125 (2014); https://doi.org/10.3906/fiz1301-7.

[23] I.V. Horichok, L.I. Nykyruy, T.O. Parashchuk, S.D. Bardashevska and M.A. Pylyponuk, Mod. Phys. Lett. B 30, 1650172 (2016); https://doi.org/10.1142/S0217984916501724.

[24] T.K. Chattopadhyay, H.G. von Schnering, W. Grosshans, W.B. Holzapfel, Physica B + C. 139, 356 (1986); https://doi.org/10.1016/0378-4363(86)90598-X.

[25] J. Peters, B. Krebs, Acta Cryst. 38, 1270 (1982); https://doi.org/10.1107/S0567740882005469.

[26] P. Basançon, C. Adolphe, J. Flahaut, P. Laruelle, Mat. Res. Bull. 4, 227 (1969); https://doi.org/10.1016/00255408(69)90098-1.

[27] W.H. Zachariasen, Acta Cryst. 1, 265 (1948); https://doi.org/10.1107/S0365110X48000703.

[28] J.E. Iglesias, H. Steinfink, J. Solid State Chem. 6(1), 93 (1973); https://doi.org/10.1016/0022-4596(73)90209$\underline{0}$.

[29] A. Michelet, G. Perez, J. Etienne, M. Darriet-Duale, C. R. Acad. Sci. 271, 513 (1970).

[30] M. Patrie, M. Guittard, M. P. Pardo, Mat. Res. Bull. 11, 3832 (1969). 
О.В. Марчук ${ }^{1}$, О.В. Смітюх ${ }^{1}$ Ю. Проць ${ }^{2}$, А.О. Федорчук ${ }^{3}$

\title{
Кристалічна структура халькогенідів $\mathbf{R}_{\mathrm{x}} \mathrm{R}^{\prime \prime}{ }_{\mathrm{y}} \mathrm{R}^{\prime \prime}{ }_{\mathrm{z}} \mathrm{PbSi} \mathrm{S}_{2}$ $\left(\mathbf{R}^{\prime}-\mathbf{L a}, \mathbf{R}^{\prime \prime}-\mathbf{T b}, \mathbf{R}^{\prime \prime}-\mathbf{E r}\right)$
}

\footnotetext{
${ }^{1}$ Волинський наиіональний університет імені Лесі Украӥнки, Луиьк, Украӥна, Marchuk.Oleg@vпи.еdи.иа ${ }^{2}$ Інститут хімічної фізики твердого тіла Товариства Макса Планка, Дрезден, Німеччина, prots@cpfs.mpg.de $3^{3}$ Львівський національний університет ветеринарної медицини та біотехнологій імені С.3. Гжицького, Львів, Украӥна, ft@иа.fm
}

\begin{abstract}
Халькогеніди, загального компонування $\mathrm{Lax}_{\mathrm{x}} \mathrm{Tb}_{\mathrm{y}} \mathrm{Er}_{2} \mathrm{PbSi}_{2} \mathrm{~S} 8$, отримували методом спікання елементарних компонентів у вакуумованих кварцевих контейнерах за температури 1320 К. Синтезовані сплави гомогенізували відпалом за температури $770 \mathrm{~K}$ протягом 500 год. Розраховано параметри елементарної комірки: $a=0,89576(3)$ нм, $c=2,65646(8)$ нм для сульфіду $\mathrm{La}_{1,2} \mathrm{~Tb}_{0,4} \mathrm{Er}_{0,4} \mathrm{PbSi}_{2} \mathrm{~S}_{8}$; $a=0,89209(1) \mathrm{Hм}, \quad c=2,63466(5) \mathrm{Hм} \quad$ для сульфіду $\mathrm{La}_{0,9} \mathrm{~Tb}_{0,2} \mathrm{Er}_{0,9} \mathrm{PbSi}_{2} \mathrm{~S}_{8} ; \quad a=0,89002(3) \mathrm{Hм}$, $c=2,62714(7)$ нм для сульфіду $\mathrm{La}_{0,67} \mathrm{~Tb}_{0,67} \mathrm{Er}_{0,67} \mathrm{PbSi}_{2} \mathrm{~S}_{8} ; a=0,88993(1)$ нм, $c=2,62973(4)$ нм для сульфіду $\mathrm{La}_{0,6} \mathrm{~Tb}_{1,2} \mathrm{Er}_{0,2} \mathrm{PbSi}_{2} \mathrm{~S}_{8} ; a=0,885161(7)$ нм, $c=2,60445$ (3) нм для сульфіду $\mathrm{La}_{0,2} \mathrm{~Tb}_{0,9} \mathrm{Er}_{0,9} \mathrm{PbSi}_{2} \mathrm{~S}_{8}$. У структурі синтезованих халькогенідів атоми статистичної суміші $(\mathrm{La}, \mathrm{Tb}, \mathrm{Er}, \mathrm{Pb})$ займають положення $18 e(\mathrm{x} \mathrm{y} 1 / 4)$, атоми $\mathrm{Si}$ займають положення $12 c(1 / 32 / 3 \mathrm{z})$. Координаційними многогранниками для атомів статистичної суміші $(\mathrm{La}, \mathrm{Tb}, \mathrm{Er}, \mathrm{Pb}) є$ призми $з$ двома додатковими атомами $(\mathrm{KЧ}=8)$, а атоми $\mathrm{Si}$, займаючи ПСТ $12 c$, мають тетраедричне оточення 3 атомів Сульфуру. Результати експерименту підтвердили, що синтезовані халькогеніди кристалізуються у структурному типі $\mathrm{La}_{2} \mathrm{PbSi}_{2} \mathrm{~S}_{8}(h R 26,167)$. Структуру $\mathrm{La}_{2} \mathrm{PbSi}_{2} \mathrm{~S}_{8}$ описано 3 позицій теорії ДКО.
\end{abstract}

Ключові слова: рідкісноземельні метали, кристалічна структура, рентгенівський метод порошку, найближче координаційне оточення (НКО), друге координаційне оточення (ДКО). 